\title{
Recent Progress in Tectonic Geomorphology in Japan, with Special Reference to Active Fault and Related Tectonic Studies
}

\author{
Haruo Yamazaki \\ Department of Geography, Tokyo Metropolitan University, Hachioji 192-03, Japan
}

\begin{abstract}
Active fault and related tectonic studies in Japan are chronologically reviewed from the viewpoint of tectonic geomorphology. The future prospects are also described based on the trends of recent progress in active fault study and the surrounding social circumstances. Since the publication of Active Faults in Japan in 1980, the field in Japan has roughly been split into two domains: the reconstruction of detailed fault behavior in Holocene times; and the elucidation of the relationship between active faults and regional tectonics. The former describes various kinds of fault behavior through the application of the trench excavation method. Although the historical activity has been uncovered on many active faults, the surveys have become increasingly difficult due to the artificial modification of land. New proposed methods such as drilling, however, have not yet developed sufficiently to substitute for trenching. The latter domain discusses various topics related to the characteristics of long-term tectonic behavior from the viewpoint of landform evolution. Studies on the net slip-rate of thrust faults and the migration of thrust fronts have brought new knowledge and ideas to landform geomorphology and seismotectonic research. The morphotectonic and seismotectonic studies in offshore and onshore regions along the Nankai Trough have sufficiently explained the tectonic and landform evolution on the island arc scale in Southwest Japan. Based on present conditions, the author proposes the following directions which should promote progress in active fault study and to utilize the results for hazard mitigation in the future: (1) to distinguish the segmentation structure in the active fault system; (2) to establish seismotectonics models for various regions in Japan; and (3) reconsideration of the recurrence interval of large earthquakes.
\end{abstract}

Key words: active fault, tectonic landform, trench, paleoseismicity, landform evolution, fault behavior

\section{Introduction}

The Japanese islands are situated in the region of the arc-trench systems which are active, complex tectonic belts fringing the outer margin of the Pacific Ocean. The Quaternary crustal movements associated with plate convergence and related tectonics play an important role in the landform evolution ranging from large to small scale in the islands.

Tectonic geomorphology comprises both research on tectonic landforms that originated due to crustal movements during Quaternary times and research on tectonic behavior that results from the forming process and evolution of tectonic landforms. Although tectonic geomorphology consists of various studies on land- forms with different scales, it is broadly classified into the following three domains: (1) active fault study; (2) study of crustal movements deduced from the shoreline heights of marine terraces; and (3) study of uplift and subsidence in mountainous areas. These studies are subdivided into several small fields in each domain.

It is beyond the author's ability to introduce the entire outline of tectonic geomorphology in the short space of one article. Therefore, this paper reviews the recent trends and features of active fault study and related geomorphological studies which have consistently been the nucleus of tectonic geomorphology in Japan and have always attracted social interest and fulfilled social needs. In the early 1990 s, several reviews were published of the tectonic geomorphology and active fault studies (e.g., Kaizuka 
1990; Okada and Ikeda 1991; Yamazaki 1994a). This paper describes the recent features and trends of study refering to the previous reviews.

\section{Brief History of Active Fault Study and Its Social Background}

The progress of active fault study in Japan consists historically of four stages. The first stage includes a period of about 50 years before World War II. The seismicity of Japan was so active in this period that large earthquakes occurred frequently in and around Honshu Island. Through research on surface ruptures associated with those earthquakes, some geologists and geographers began to think that a fault movement is not the result but the source of earthquakes (Koto 1893), and that an active fault has the potential to cause future large earthquakes (Tada 1927). Although these ideas were suggestive, the underdeveloped seismology and Quaternary research of the time could not sufficiently explain the relationship between earthquakes and tectonics.

The study of fault topography also became popular in this period. Numerous fault scarps were pointed out and described throughout Japan using topographical maps of $1: 50,000$ scale. However, lacking observations and evidence of the geological viewpoint, such study could not fully develop into the reconstruction of fault movements that created the fault scarps.

Active fault study established its philosophy in the second stage, the period of two and half decades after World War II, supported by the progress of focal mechanism solutions in seismology, tephrochronology and radiometric dating in Quaternary research, among others. In 1965 , active fault study formed part of the national project called the Earthquake Prediction Program in Japan. Evidence of strike-slip movements was found along major active faults such as the Atera Fault in central Japan (Sugimura and Matsuda 1965) and the Median Tectonic Line (MTL) in southwestern Japan (Okada 1968 and Kaneko 1966) through detailed observations of landforms.

The third stage, consisting of the 1970 s, was an age of discovery of active faults in Japan. The existence of many faults that had relatively low activities was uncovered one after another through the interpretation of aerial photographs and field investigations on landform evolution. At the end of this stage, the Research Group for Active Faults of Japan, which consisted mainly of geologists and geomorphologists, systematically compiled data on almost all active faults in Japan. The group completed a book with sheet maps and inventories titled Active Faults in Japan in 1980. The publication of the book was an epochmaking event in the history of active fault study. This also made it possible for scientists in other disciplines as well as geographers to have easy access to active fault data, and to discuss active faults by combining their individual data.

The fourth stage includes the period since 1980. The publication of Active Faults in Japan was a turning point for active fault study in Japan. A new direction was sought to achieve progress in active fault study. According to Yamazaki (1994a), study in this period can be divided into the following areas. One area included studies to determine the history and style of individual fault movements for some major faults in Japan. Another area sought to explain the relationship between the movements of individual active faults and regional tectonics. The following paragraphs give the details of these studies.

Active fault study was affected by several social factors in this period. One was the campaign of criticism of the Earthquake Prediction Program in Japan arising in the early 1990s. Although this criticism was directed against the observation system for the precursory phenomena of earthquakes, the government budget for active fault research was reduced by more than $30 \%$ in the 1994 fiscal year.

The occurrence of the 1995 Hyogo-ken Nanbu Earthquake had another significant effect on active fault study. The recurrent movement of a group of active faults called the Rokko Fault System running along the western coast of Awajishima Island and eastern foot of the Rokko Mountains generated a shallow earthquake with a magnitude of 7.2 on the 
Richter scale. Because of the severe damage in Kobe with over 5,500 fatalities, people feared the existence of active faults that have the potential to be the source of future large earthquakes. Therefore the government decided to launch a new research project for earthquake hazard assessment of active faults a half year after the earthquake. The effect of this major earthquake on study is discussed in the section on "Future Prospects of Active Fault Study in Japan."

\section{Study on the Reconstruction of Precise Fault Movements: Methodological Evolu- tion of the Study}

Study of the reconstruction of fault behavior which aims to extract paleo-faulting events and paleoseismicity from the strata and to estimate the age of the events, has progressively developed since 1980. This sudden development resulted from the introduction of trench excavation surveys, originated by Sieh (1978) in California. The method of the survey is to dig a narrow trench in order to cross an active fault trace, and to detect faulting events through detailed observation of the displaced young strata which appear on both walls of the trench. Trench excavation surveys have been systematically carried out in research projects by some groups and institutes such as the group of researchers in universities, the Geological Survey of Japan, and the Central Research Institute of the Electronic Power Industry. The number of trenching sites dug over 15 years totalled 67 for 25 active fault systems in Japan by March 1994. Figure 1 shows the annual changes in number of trench excavations in Japan.

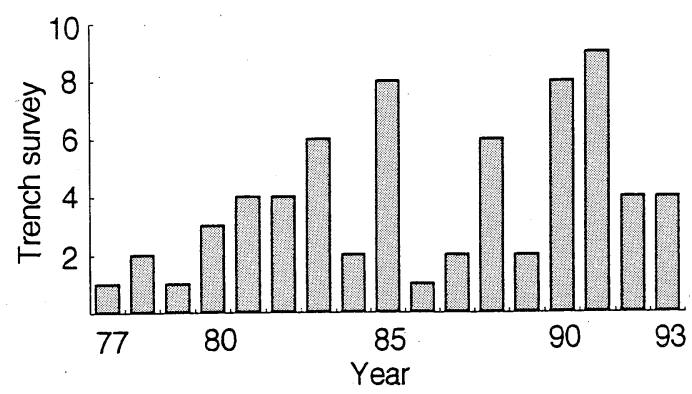

Figure 1. Annual change in the number of trench survey sites (Yamazaki 1994a).
In the later half of the 1980 s, trench surveys encountered some problems, including the difficulty in detecting favorable sites for trenching in urbanized areas and a shortage of young researchers who wanted to take part in active fault study. Researchers therefore had to originate various new methods to reconstruct fault behavior and paleoseismicity.

Sangawa (1990) showed that ground rupture and fossil liquefaction which cut through archeological sites yield useful information for the reconstruction of paleoseismicity. Drilling or coring surveys also proved useful in finding and assessing active faults buried beneath the alluvial plain and sea bottom (e.g., Matsuda et al. 1988; Shimazaki et al. 1986). On the basis of detailed seismic profiles obtained from Beppu Bay, Kyushu, Nakata (1995) showed that the Holocene behavior of sea-bottom active faults accorded well in their time-predictable recurrence model (Shimazaki and Nakata 1980) of fault movement, and pointed out that these faults had a high potential for recurrent movement in the near future.

Recently, many researchers have become interested in lake sediment as a seismograph that maintains a long-term record of paleoseismicity in adjacent regions. When a fault movement interrupts the drainage of a lake, the lacustrine will record the environmental change caused by the sudden rise in the lake level. Strong earthquake motion also causes a turbidity current on the bottom of a lake. Inouchi et al. (1993), Miyata et al. (1990) and Fukusawa et al. (1994) discussed the age of paleoseismic events through the detailed analysis of drilling cores obtained from Lake Biwa and Lake Suigetsu, southwestern Japan.

Thus a recent feature of active fault studies was the diversification of research methods for the reconstruction of paleoseismicity and fault movements.

\section{Results of study on the reconstruction of fault movements}

Important knowledge on the behavior of active faults in Japan has been obtained from the above-mentioned studies since 1980. Such studies revealed the general features of the recurrence interval of onshore active faults in 


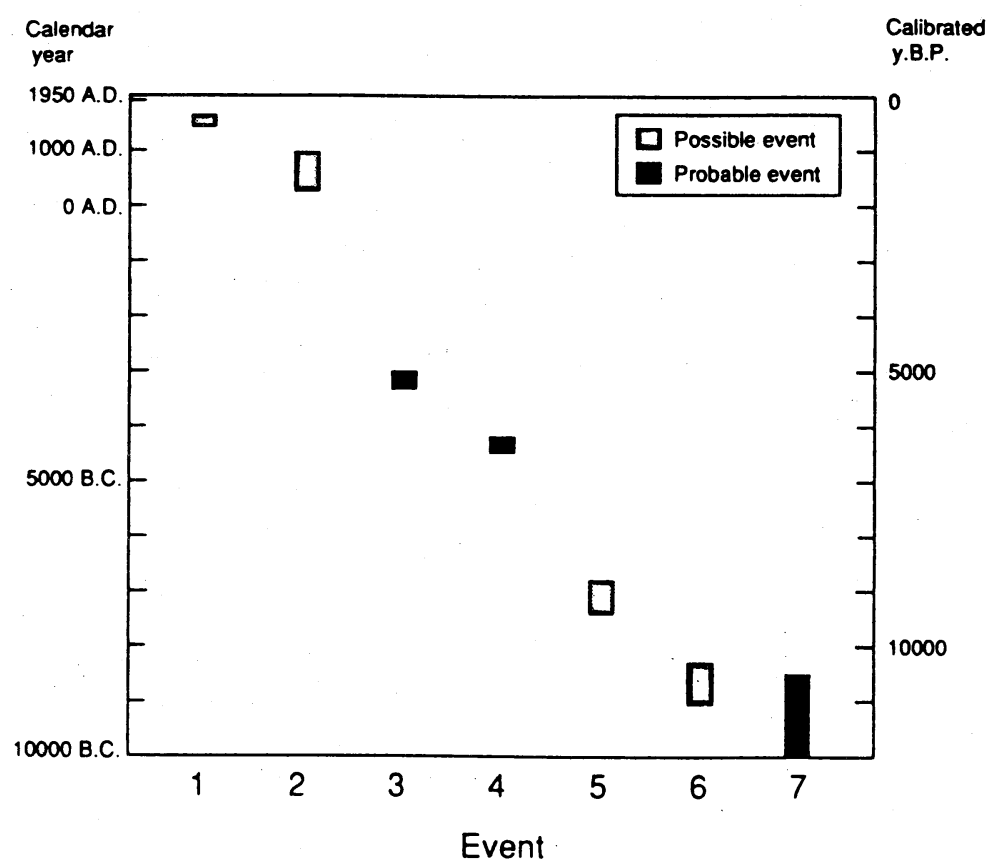

Figure 2. Recurrence interval of the Atera Fault (Toda 1995).

Japan. Some results from the major active faults such as the Atera fault (Awata 1988; Toda et al. 1995), the Tanna fault (Tanna Fault Trenching Research Group, 1983) and others (e.g., Okumura et al. 1994; Okada 1992) confirmed that the recurrence intervals of almost all active faults in Japan are longer than 1,000 years (Figure 2).

Another result is that the sources of some huge earthquakes described historically were uncovered. Since the end of the 1980s, trench surveys in Japan have focused on the elucidation of the precise age of the last event and the recurrence interval of individual active faults for use in hazard assessment. Many small-sized trenches were excavated on an active fault system. The increase in trench number after 1990 in Figure 1 reflects this focus.

Toda et al. $(1994,1995)$ worked out the fact that the 1586 Tensho Earthquake, which was an exceptionally huge earthquake in central Japan was caused by the recurrent movement of the Atera fault system after a dormant period of 2,000 years. Previously, the fault was thought to be one of the marked faults that have a high potential to cause a large earthquake in the near future, because of the histor- ical record on faulting was not available in spite of the high activity estimated from the geological data. However, the confirmation of the age of the last event drastically changed the evaluation of the fault from dangerous to safe. Figure 3 shows the active faults for which historical movements were revealed through the above mentioned surveys by 1995 .

Further results concern the behavior pattern of each fault in an active fault system. In the latter half of the 1980 s, active fault study gradually changed its direction toward attempts to distinguish the segment structure of active fault systems, stimulated by studies in the USA (e.g., Schwaltz and Coppersmith 1984). Although Okada (1992) recently proposed a tentative plan for the segment structure of the MTL, chronological data on seismic events were still insufficient to determine the segment and barrier systems of other active faults in Japan.

However, the curious behavior of each active fault constituting an earthquake fault system was revealed in the Kita-izu fault system including the Tanna fault in its central region. The Kita-izu fault system caused the 1930 Kitaizu Earthquake of magnitude 7.2 on the Richter scale. Surface breaks intermittently appeared 


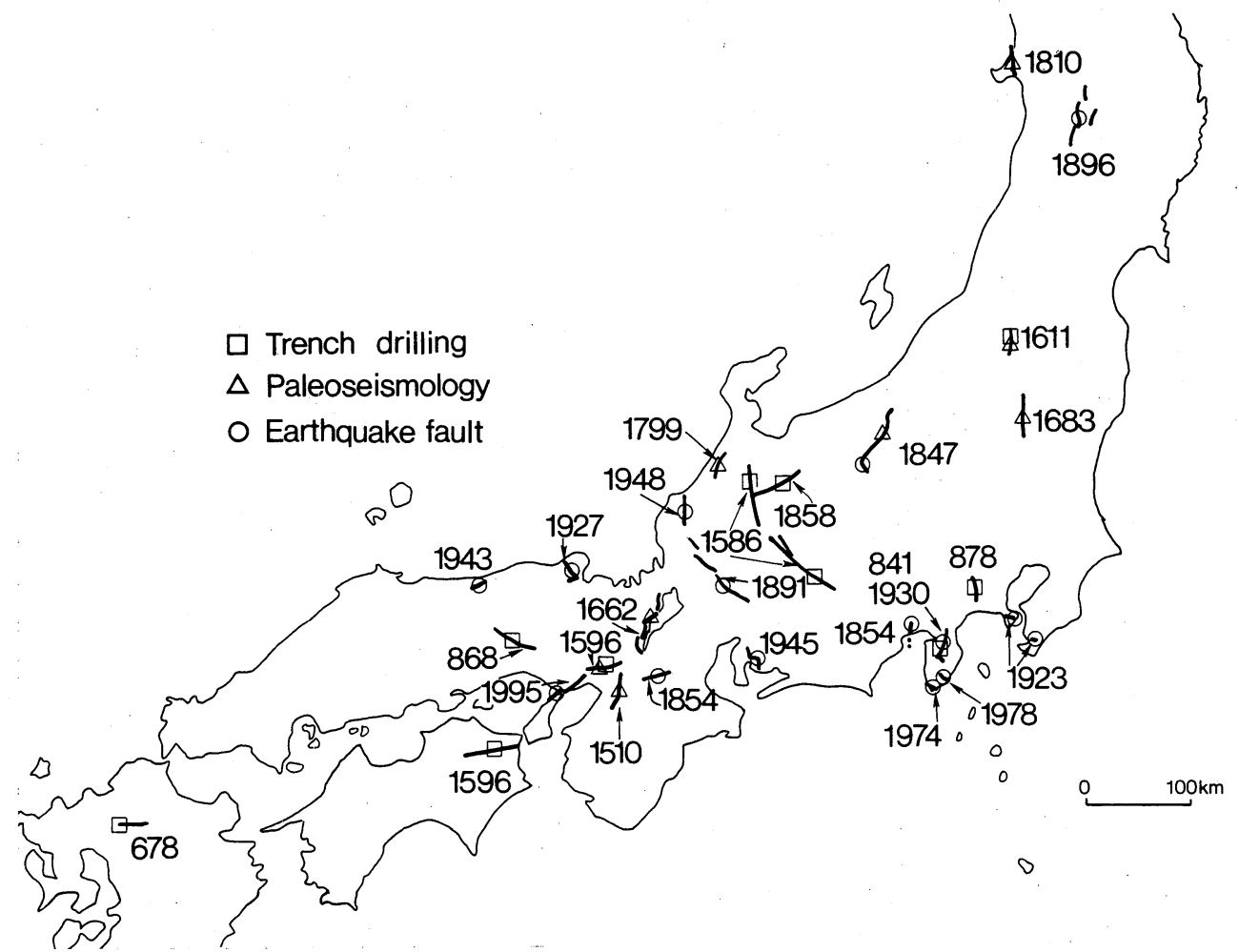

Figure 3. Active faults for which historical reactivating was identified by various paleoseismic studies (Yamazaki 1994a).

Numerals indicate the year of events. Symbols on the fault lines show the method used to identify the events.

for $35 \mathrm{~km}$ along the active fault system. Several trenches excavated on each surface break revealed that the ages of fault events before 1930 were different from each other in active faults which moved together in 1930. In this fault system, the Tanna fault, which has the most conspicuous tectonic landforms, showed the highest activity and frequent recurrence intervals of 700-1,000 years. On the other hand, trenches on the Ukihashi Central fault and Himenoyu fault comprising the southern segments of the 1930s break indicated that the last events before 1930 had occurred more than 4,000 years ago (Tsukuda and Yamazaki 1984; Mizuno 1988).

These facts suggest that the Kita-izu fault system consists of the main Tanna fault and other subsidiary faults. Although the main fault always moves during every seismic event related to the Kita-izu fault system, the behaviors of subsidiary faults are irregular. The same case was recognized on the Nobi Earthquake fault system that caused the 1891 Great Nobi Earthquake. The Neo-dani fault, the most active segment in the system, has a recurrence interval of 3,000 to 4,000 years (Okada and Matsuda 1992), while the last event before 1891 of the Umehara fault, situated in the southern part of the system, is estimated to be about 20,000 years ago (Okada et al. 1992). However, no one has yet proposed the reason and model explaining these curious facts.

\section{Study on the Relationship between Active Faults and Landform Evolution or Tec- tonics}

As Ishibashi (1978) pointed out, seismicity is a product of regional tectonics. Therefore it is important for tectonic geomorphology and earthquake prediction to know the setting of active faults in regional and global tectonics. Active fault study since 1980 has also a tried to reveal the implications of active fault behavior 
in the regional tectonic and plate tectonic frameworks.

\section{Reconsideration of net slip of thrust faults}

The displacement and slip rate of dip-slip faults are usually estimated from the relative height of the same geomorphic surfaces on both sides of a fault. Ikeda and Yonekura (1986), however, thought that it is difficult to estimate the precise slip rate from the relative height in the case of low-angle thrust faults that have a large horizontal-shortening component, and developed a new method to estimate the net slip component of low-angle thrust faults. They then applied the method to the Tagiri fault in the Ina Valley, central Japan, and showed that the thrust fault in the Ina Valley has first-class activity with a net slip rate of 3 to $6 \mathrm{~mm}$ per year. This fact shattered the commonly held belief that almost all thrust faults in Japan have second-class activity with slip rates of less than $1 \mathrm{~mm}$ per year, and suggested that all thrust faults in northeast Japan and the Kinki Region should be reconsidered and their true activity estimated using the net slip rate.

\section{Migration of the thrust front and landform evolution}

Major active thrusts that form conspicuous geomorphic boundaries between ranges and basins or plains in Japan frequently show geological and geomorphic evidence of thrust front migration during the Quaternary toward the downthrown side of the main thrust (e.g., Ota and Sangawa 1982; Yamazaki 1984; Sangawa et al. 1985). The migration of the thrust front means that a thrust newly branched off the main thrust with a low angle gradually increases its activity instead of the main thrust. As the reason for migration of the thrust front, Ikeda and Yonekura (1986) explained that the accumulation of soft sediments causes the low-angle thrust to branch off the boundary fault of the basin into unconsolidated basin fills. Suzuki (1988) and Watanabe (1985) examined the relationship between the fault migration and the landform evolution in basins of northeast Japan, and supported the abovementioned explanation of Ikeda and Yonekura (1986).
On the other hand, Yamazaki (1992) compiled data on the features of Quaternary tectonics in the onshore plate boundary region around Izu Peninsula, central Japan, and discussed the function of active faults in a plate convergence process. Based on the landform evolution of the onshore extension of Sagami and Suruga Troughs, Yamazaki $(1984,1992)$ showed the migration of faulting toward the Izu Peninsula side. The geology of these regions comprises the thick and deformed accumulation of trough fills since the Pliocene. Several parallel thrusts divide the region into mountains, hills and alluvial lowland (Figure 4). The most Izu-ward thrust shows the highest activity with a vertical slip rate of 3 to $7 \mathrm{~mm}$ per year. The activity of the faults gradually decreases as they go farther from the Izu Peninsula. On the other hand, the emergence age of fault movements becomes younger toward the Izu Peninsula. From these facts, Yamazaki (1992) interpreted that the active faults in the region were imbricated thrusts branched off the subducting plate boundary into the accretionary prism consisting of the trough fill sediments. $\mathrm{He}$ also thought that the thrust migration was caused by the increase in thrust angle of imbricated faults and horizontal compression stress in the accretionary prism. He reconstructed the behavior of the imbricated thrust in Ashigara Plain, northwestern extension of the Sagami Trough, based on the geomorphic and geological information obtained from both sides of the fault, and showed that the fault had a long recurrence interval of more than 2,000 years (Yamazaki 1994b).

Although there is a big difference in tectonic background between the inland basins in northeastern Japan and the plate convergence zone in central Japan, the migration of thrust fronts has constructed tectonic landforms with a similar appearance in both regions. Thus the migration of faulting that occurs everywhere in Japan is an important subject that should be elucidated in detail to understand the long-term changes of geological and geomorphic environments. Recently, the subject has attracted great interest as a means to estimate the future variation of the geologic environment from the view-point of radioactive waste disposal. 


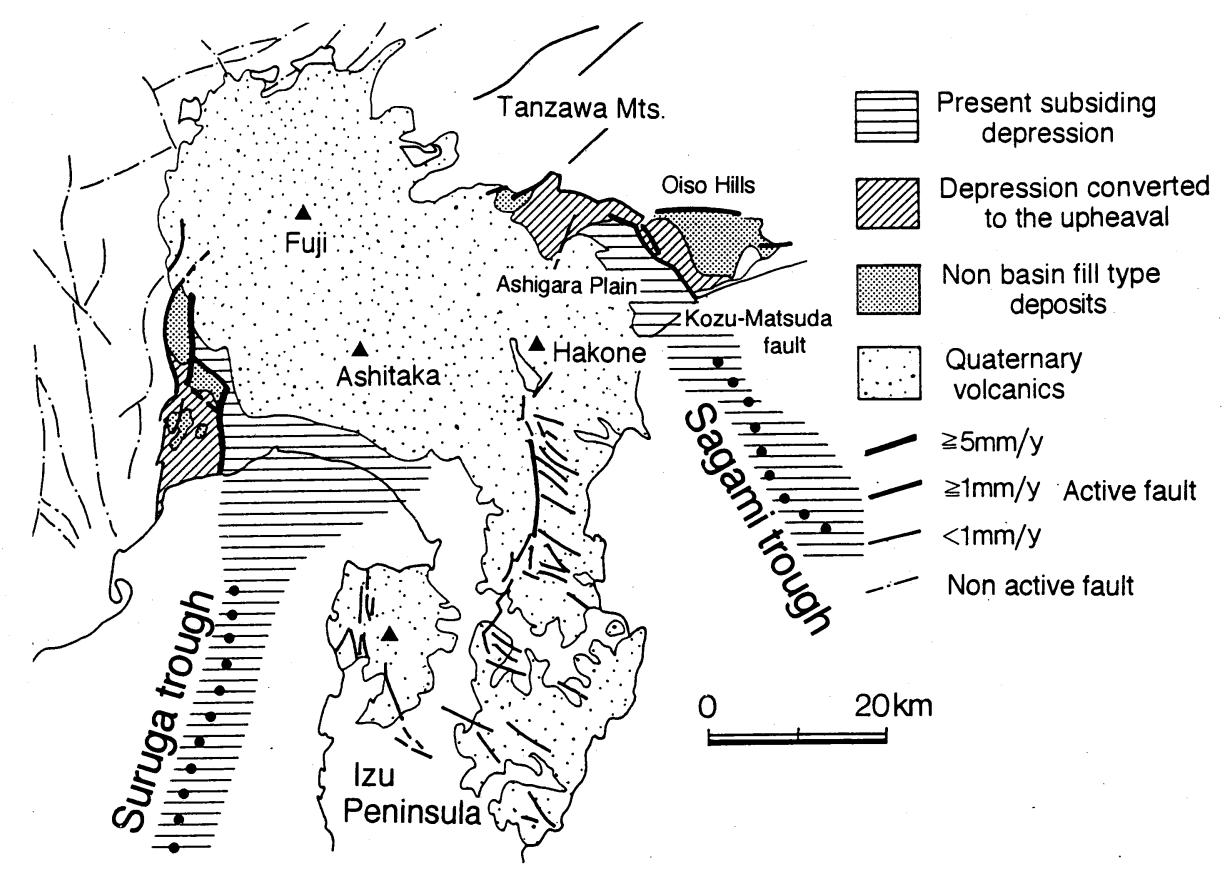

Figure 4. Distribution of active faults and Quaternary sediments in the plate convergence region of the northern margin of Izu Peninsula (Yamazaki 1992).

Fault name: 1. Iriyama-Shibakawa thrust; 2. Iriyamase-Omiya-Agoyama fault system; 3. Kannawa fault system; 4. Kozu-Matsuda fault; 5. Kita-Izu fault system; 6. Hirayama fault; 7. Shibusawa fault.

\section{Tectonic landforms and active faults in the off shore region}

Since the end of the 1980s, morphotectonic structures and seismotectonics in offshore region have attracted much attention from researchers (e.g., Awata and Sugiyama 1989; Sugiyama 1990). In this trend, Sugiyama (1992, 1994) and Tsukuda (1992) showed the significance of oblique subduction of the Philippine Sea Plate beneath the Eurasian Plate and rightlateral movement of the MTL in the structural and morphotectonic development of southwest Japan. The outer arc of southwest Japan, between the Nankai Trough and the MTL, consists of the following four morphotectonic zones parallel to the Nankai Trough: the inner trench slope, the outer ridge, the forearc basin and the forearc rise from the offshore side. The forearc basin, however, does not extend far along the trough direction but is subdivided into six subsiding units by the N-S trending submarine spurs extending from the major promonotories of Shikoku and Honshu Islands.
Sugiyama (1994) noticed that the N-S trending spurs bend their direction to the southwest offshore, and continue to the outer ridges parallel to the Nankai Trough to form an inverted L-shaped rise (Figure 5). He also pointed out that the submarine morphotectonic features, such as the inverted L-shaped rise, originated from the accumulation of coseismic crustal movements associated with interplate earthquakes, because the crustal deformation pattern of the 1946 Nankai-do Earthquake coincided with the morphotectonic pattern of the outer ridge and forearc basin.

Furthermore, the Quaternary right-lateral slip of the MTL, caused by the oblique subduction of the Philippine Sea Plate, affects the formation of morphotectonic patterns of the inner arc region in southwest Japan (Tsukuda 1992). The basins and ridges with elliptical shapes developing along the northern side of the MTL show the en-echelon arrangement. Tsukuda (1992) and Sugiyama (1994) pointed out that these structures were generated by the crustal drag of the inner arc region associated with the 


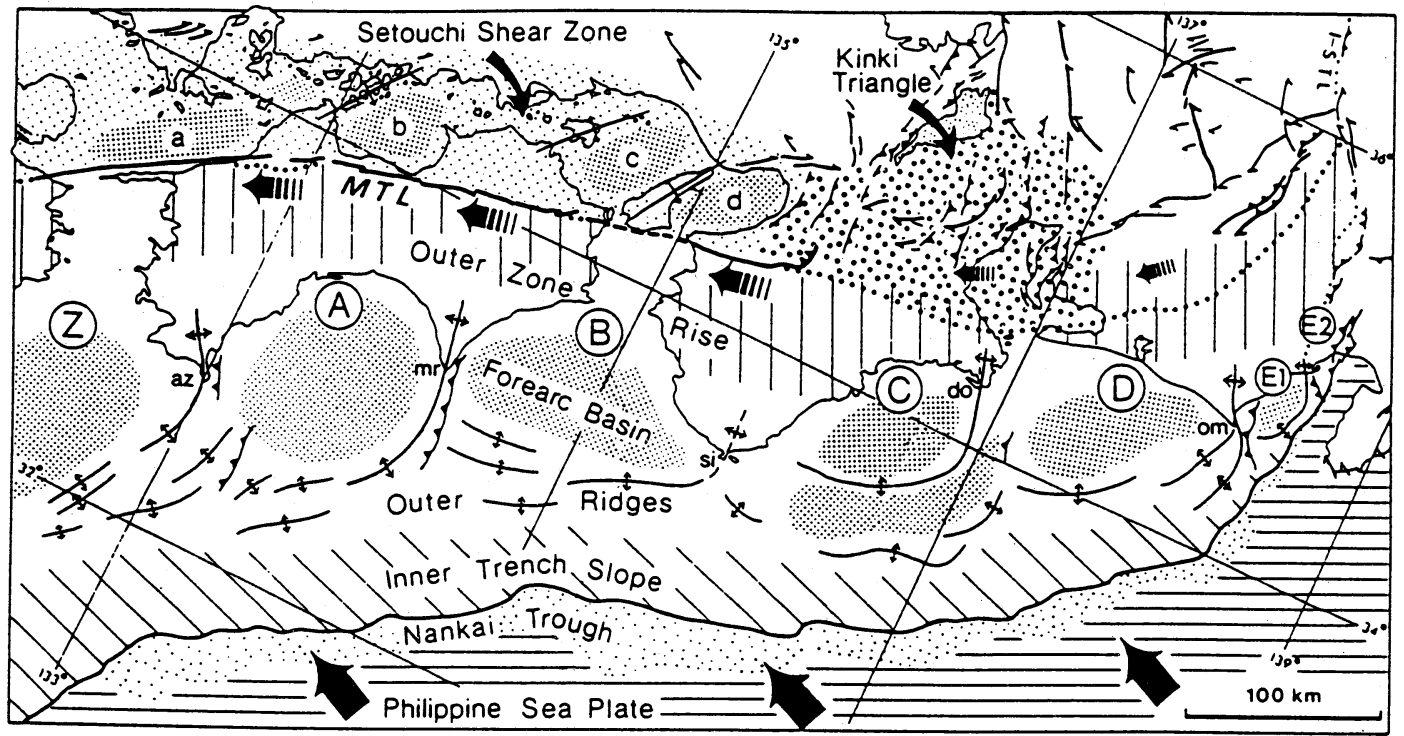

Figure 5. Active tectonic map of southwest Japan (Sugiyama 1992, 1993).

Areas $Z$ and A-E2 are the structual units of the forearc zone. Each unit except for E2 consists of a set of an inverted L-shaped ridge and a forearc basin.

Basins in Setouchi regin are: a: Iyo-nada; b: Hiuchi-nada; c:Harima-nada; d: Osaka Bay.

Names of capes are: az: Cape Ashizuri; mr: C. Muroto; si: C. Shiono-misaki; d: C. Omae-zaki.

right-lateral slip of the MTL and accumulation of the movement during the Quaternary. This type of movement has formed the subsiding sedimentary basins and intervening ridges along the southern margin of the inner southwest Japan arc.

On the other hand, Maemoku (1988) and Maemoku and Tsubono (1990) showed that the number of Holocene marine terraces in Shikoku and the Kii Peninsula region was significantly fewer than that of interplate earthquakes with a recurrence interval of about 150 years. They estimated that the seismic events which generated the Holocene terraces had occurred at 300- to 1,500-year intervals. Considering the relationship between the Genroku and the Taisho Kanto earthquakes (Matsuda et al. 1978), Sugiyama (1994) concluded that the Holocene terraces were formed by intra-plate faulting which had a 300- to 1,500-year recurrent interval and the coseismic uplift associated with the interplate faulting was not reserved for a long period due to the elastic deformation of the overriding plate.

Seismotectonic and tectonic geomorphological studies in southwest Japan have achieved revolutionary progress in recent years through the detailed examination of morphotectonic structures in the offshore and the Holocene marine terraces. The trend of these studies will play an important role in constructing a regional tectonics model which is indispensable to understand the tectonic mechanisms of earthquakes.

\section{Future Prospects for Active Fault Study in Japan}

Yamazaki (1994a) summarized active fault study in Japan as of 1993 and described the problems and future prospects. He pointed out the following three problems:

(1) Although trench survey methodology faces various problems and difficulties, it is difficult to develop a substitute method for trench surveys.

(2) Active fault study has lost a clear objective.

(3) Active fault study in Japan has been carried out in project-type studies. This type of study has resulted in a scarcity of young researchers for active fault study.

These were also comments during the strong campaign of criticism of the Earthquake Prediction Program. However, the 1995 Hyogo-ken Nanbu Earthquake that occurred on January 
17,1995 , drastically changed the circumstances surrounding active fault study. After the earthquake, the government decided to promote seismic hazard assessment for over 100 major active faults in Japan. Seismic hazard assessment for active faults involves confirming the past fault behavior in Holocene times and estimating the potential for movement recurrence in the near future. These data will be used by various governmental activities to reduce earthquake hazards in the future.

Thus active fault study obtained a clear objective and new problems after the earthquake. However, the objective does not seem to be a real objective that will result in great progress in active fault study. The government and public want active fault study to provide useful information and knowledge for reducing seismic damage and the tragedies caused by active fault movement. The demand for more precise and detailed information on active fault behavior and seismotectonics in Japan will increase in the future because it is a national desire to construct a society free from earthquake hazards. To meet those demands, we have to indicate clear objectives and the correct direction for future active fault study. The author proposes the following three major items drawn from the trends and problems of recent study:

(1) The segment structure of major active fault systems.

The barriers in segmented fault systems have the potential to become a rupture nucleation (Tsukuda 1991). Recognition of the barriers is very important for improvement of continual observatory systems for precursors of large earthquakes. Therefore we need a great deal of information on the paleoseismicity and activity of each discrete fault constituting a fault system to distinguish the segmented structure of fault strands.

Trenching surveys in residential areas, however, has become increasingly difficult due to urbanization and artificial modification. It is necessary to develop various new methods for the determining the segmented structure, in parallel with improvement of the trench method.

Lacustrine analysis is one promising method to provide useful information on paleoseismicity because the layer accumulates, like a tape recorder, the continual geological record. In this case, it may be necessary to improve the analytic method to obtain more refined information.

(2) Establishment of a regional seismotectonic model.

A seismotectonic model implies the kind of model that explains the relation between an earthquake, an active fault and the regional or plate tectonics. Ishibashi $(1988 \mathrm{a}, \mathrm{b})$ constructed an excellent model showing the plate tectonic implications for a future probable earthquake, called the Odawara Earthquake, in the northwestern part of Sagami Bay. In this model, he clearly estimated the locality of the source fault, the magnitude of the earthquake and the probable timing of event occurrence. This information is indispensable for the mitigation of earthquake hazards.

The author thinks that we should liven up the study of the implications of active faults in the regional tectonic setting and should construct seismotectonic models which describe the relationship between the behavior of active faults and regional tectonics, not only in Sagami Bay but also in various other parts of Japan. Complementarity of seismotectonic models in many parts of Japan will refine the ability to predict future large earthquakes produced by onshore active faults.

(3) Reconsideration of the recurrence interval estimated from past surface ruptures.

The 1995 Hyogo-ken Nanbu Earthquake presented a new problem to active fault study. Although fault activity was clearly detected for a distance of $50 \mathrm{~km}$ by the fault mechanism and aftershock distribution, the surface break of only $10 \mathrm{~km}$ appeared in Awajishima Island. This fact suggests that the earthquake recurrence interval deduced from the surface displacements and ruptures at trench sites might underestimate the frequency of large earthquakes produced from an active fault. This problem may compel active fault research to reconsider the significance of the recurrence interval derived from surface faulting evidence. 


\section{Acknowledgments}

The main points of this paper were devised through many discussions in the Seismotectonic Research Section, Geological Survey of Japan, to which author belonged in 1993. The author thanks Dr. Yoshihiro Kinugasa, former head of the section, and his previous colleagues for their helpful discussions, suggestions and continuous encouragement in active fault and seismotectonic studies.

(Received Feb. 2, 1996) (Accepted May 25, 1996)

\section{References}

Awata, Y. 1988. Trenching study of the Atera fault 1985, Magome site, Nagano Prefecture. Active Fault Research 5: 50-54. (J)

Awata, Y., and Sugiyama, Y. 1989. Geological structure due to the right-lateral reverse faulting accompanied with the large earthquakes along the Nankai Trough. Jounal of the Seismological Soiety of Japan 42: 231-233. (J)

Fukusawa, H., Koizumi, I., Okamura, M., and Yasuda, K. 1994. Historical earthquake, flood and human activity events recorded in the Holocene sediments of Lake Suigetsu, Fukui Prefecture, central Japan. Journal of Geography 103: 127-139. (JE)

Ikeda, Y., and Yonekura, N. 1986. Determination of late Quaternary rates of net slip on two major fault zones in central Japan. Bulletin of the Derpartment of Geography, University of Tokyo 18: 49-63.

Inouchi, Y., Kinugasa, Y., Kumon, F., Yasumatsu, S., Nakano, S., and Shiki, T. 1993. Turbidites in Lake Biwa as indicators of intensity of paleoearthquakes. Memoirs of the Geoogical Society of Japan 39: 61-70. (JE)

Ishibași, K. 1978. Jishin yochi no jissaiteki senryaku. (Practical strategy for the earthquake prediction). In Jishin yochi no houhou (Method of the earthquake prediction), ed. T. Asada, 193-209. Tokyo: University of Tokyo Press. (J)

Ishibashi, K. 1988a. 'West Kanagawa Earthquake' and earthquake prediction I. Kagaku 58: 537-547. (J)

Ishibashi, K. 1988b. 'West Kanagawa Earthquake' and earthquake prediction II. Kagaku 58: 762-767. (J)

Kaizuka, S. 1990. Studies on tectonic landforms-An overview. In Hendou chikei (Tectonic landforms) ed. Yonekura, N., Okada, A., and Moriyama, A. 117. Tokyo: Kokon-shoin. (J)

Kaneko, S. 1966. Transcurrent displacement along the Median Tectonic Line, South-west Japan. New Zealand Journal of Geology and Geophysics 9: 45-59.

Koto, B. 1893. On the cause of the Great Earthquake in central Japan, 1891. Journal of the Science
College of the Imperial University 5: 295-353.

Maemoku, H. 1988. Holocene crustal movement in Muroto Peninsula, southwest Japan. Geographical Review of Japan 61 A: 747-769. (JE)

Maemoku, H., and Tsubono, K. 1990. Holocene crustal movement in the southern part of Kii Peninsula, outer zone of Southwest Japan. Journal of Geography 99: 349-369. (JE)

Matsuda, T. Ota, Y., Ando, M., and Yonekura, N.1978. Fault mechanism and recurrence time of major earthquakes in southern Kanto district Japan, as deduced from coastal terrace data. Geological Society of America Bulletin 89: 1610-1618.

Matsuda, T., Yui, M., Matsushima, Y., Imanaga, I., Hirata, D., Togo, M., Kashima, K., Matsubara, A., Nakai, N., Nakamura, T., and Matsuoka, K. 1988. Subsurface study of Isehara Fault, Kanagawa Prefecture, detected by drilling-Depositional environments during the last 7,000 years and fault displacement associated with the Gangyou Earthquake in A.D.878- Bulletin of the Earthquake Research Institute, University of Tokyo 63: 145-182. (JE)

Miyata, Y., Yamamura, T., Nabetani, A., Iwata, T., Obata, M. Yuki, T., and Tokuhashi, S. 1990. Formation processes of lacustrine deltas - an example from the Echi River Delta, Lake Biwa-. Geological setting and sedimentary facies. Journal of the Geological Society of Japan 96: 839-858. (JE)

Mizuno, K. 1988. Trenching study for the Himenoyu Fault 1983 Himenoyu site, Naka-izu. Active Fault Research 5: 29-34. (J)

Nakata, T. 1995. Paleoseismic study on the submarine active faults. In Kojishin wo saguru (Research of paleoseismicity), ed. Y. Ota and K. Shimazaki, 168192. Tokyo: Kokon Shoin. (J)

Okada, A. 1968. Strike-slip faulting of late Quaternary along the Median Dislocation Line in the surroundings of Awa-Ikeda, northeastern Shikoku. The Quaternary Research (Daiyonki-Kenkyu) 7: 1526. (JE)

Okada, A. 1992. Proposal of the segmentation on the Median Tectonic Line active fault system. Memoirs of the Geological Society of Japan 40: 1530. (JE)

Okada, A., and Ikeda, Y. 1991. Active faults and neotectonics in Japan. The Quaternary Research (Daiyonki-Kenkyu) 30: 161-174.

Okada, A., Matsuda, T. 1992. Late Quaternary activity of the Neodani (Neo-Valley) fault at Midori and Naka, Neo Village, central Japan. Journal of Geography 101: 19-37. (JE)

Okada, A., Watanabe, M., Ando, M., Tsukuda, T., and Hirano, S. 1992. Estimation of paleo-seismicity in the Nobi Fault System, central Japan-Excavation study of the Umehara Fault, central strand in the Nobi Active Fault System-. Journal of Geography 101: 1-18. (JE) 
Okumura, K., Shimokawa, K., Yamazaki, H., and Tsukuda, E. 1994. Recent surface faulting events along the middle section of the ItoigawaShizuoka Tectonic Line-Trenching survey of the Gofukuji Fault near Matsumoto, central Japan-. Journal of Seismological Society of Japan 46: 425-438. (JE)

Ota, Y., and Sangawa, A. 1982. Active faults in the eastern foot area of the Suzuka Range, Central Japan. Geographical Review of Japan 57A: 237262. (JE)

Sangawa, A. 1990. Evidences of paleoearthquakes found out in some archaeological sites. Journal of Geography 99: 471-482. (JE)

Sangawa, A., Kinugasa, Y., Okumura, K., and Yagi, H. 1985. Neotectonics along the eastern rim of the Nara Basin. The Quaternary Research (DaiyonkiKenkyu) 24: 85-97. (JE)

Schwaltz, D. P., and Coppersmith, K. J. 1984. Fault behavior and characteristic earthquakes: Examples from the Wasatch and San Andreas fault zone. Journal of Geophysical Research 89: 56815698.

Shimazaki, K., and Nakata, T. 1980. Time-predictable recurrence model for large earthquakes. Geophysical Research Letters 7: 279-282.

Shimazaki, K., Nakata, T., Chida, N., Miyatake, T., Okamura, M., Shiragami, H., Maemoku, H., Matsuki, H., Tsuji, M., Kiyokawa, S. and Hirata, K. 1986. A preliminary report on the drilling project of submarine active faults beneath Beppu bay, southwest Japan, for long-term earthquake prediction. Active Fault Research 2: 83-88. (J)

Sieh, K. 1978. Prehistoric large earthquakes produced by slip on the San Andreas fault at Pallet Creek, California. Journal of Geophysical Research 83: 3907-3939.

Sugimura, A., and Matsuda, T. 1965. Atera fault and its displacement vectors. Geological Society of America Bulletin 76: 509-522.

Sugiyama, Y. 1990. Seismotectonics of the Suruga Bay and Enshu-nada Region. Journal of the Seismological Society of Japan 43: 439-442. (J)

Sugiyama, Y. 1992. Neotectonics of the forearc zone and the Setouchi Province in southwest Japan. Memoirs of the Geological Society of Japan 40: 219233. (JE)

Sugiyama, Y. 1994. Neotectonics of southwest Japan due to the right-oblique subduction of the Philippine Sea Plate. Geofisica Internacional 33: 53-76.

Suzuki, Y. 1988. Active tectonics and evolutional pro- cess of the Shinjo and Yamagata Basins, Northeast Japan. Geographical Review of Japan 61 A: 332-349. (JE)

Tada, F. 1927. Katsudansou no 2 shurui. Geographical Review of Japan 3: 930-933. (J)

Tanna Fault Trenching Research Group 1983. Trenching study for Tanna fault, Izu, at Myoga, Shizuoka Prefecture, Japan. Bulletin of the Earthquake Research Institute, University of Tokyo 58: 797-830. (JE)

Toda, S., Inoue, D., Takase, N., Kubouchi, A., and Tomioka, N. 1994. Journal of the Seismological Society of Japan 47: 73-77. (JE)

Toda, S., Inoue, D., Kubouchi, A., Takase, N., and Nikaido, M. 1995. Paleoseismicity of the Atera Fault System and 1586 Tensho Earthquake: Trenching studies at Ogo, Aonohara and Dendahara, central Japan. Journal of the Seismological Society of Japan 48: 401-421. (JE)

Tsukuda, E. 1991. Geometrical barriers on faults and their rupturing process. Journal of Geography 100: 417-428. (JE)

Tsukuda, E. 1992. Active tectonics of Southwest Japan arc controlled by the westward translation of the forearc sliver. Memoirs of the Geological Society of Japan 40: 235-250. (JE)

Tsukuda, E., and Yamazaki, H. 1984. Excavation survey of active faults for earthquake prediction in Japan with special reference to the Ukihashi Central fault and the Atera fault. Report of the Geological Survey of Japan 263: 349-361.

Watanabe, M. 1985. A fault model for mountain building and basin-forming in Fukushima Basin region, Northeast Japan. Geographical Review of Japan 58A: 1-18. (JE)

Yamazaki, H. 1984. Neotectonics of the South Fossa Magna in central Japan deduced from active faults. The Quaternary Research (Daiyonki-Kenkyu) 23: 129-136. (JE)

Yamazaki, H. 1992. Tectonics of a plate collision along the northern margin of Izu Peninsula, central Japan. Bulletin of the Geological Survey of Japan 43: 603-657.

Yamazaki, H. 1994a. The present condition and future prospects of the active fault study in Japan. Journal of Geography 103: 780-798. (JE)

Yamazaki, H. 1994b. Reconstruction of fault behavior and paleoseismicity in the onshore plate convergence zone, central Japan. Proceedings of the workshop on paleoseismology, USGS Open-file Report 94-568: 205-207. 